\title{
Komunistyczna Partia Polski dziś KPP jako przykład partii marginalnej
}

\author{
Communist Party of Poland today \\ $\mathrm{CPP}$ as an example of marginal party
}

\author{
Piotr Obacz
}

\section{Abstrakt}

Artykuł poświęcony jest współczesnej Komunistycznej Partii Polski - jej celom i kierunkom działania, a nade wszystko temu, w jaki sposób nawiązuje do przeszłości, jak traktuje spuściznę organizacji, do których się odwołuje, tj. przede wszystkim KPRP i KPP okresu międzywojennego, i w końcu jakich udziela odpowiedzi na wyzwania współczesności sięgając do przeszłości jako źródła politycznych inspiracji.

Celem autora opracowania jest przybliżenie, jak rysuje się poczucie związku historycznego KPP z dawniejszymi polskimi partiami komunistycznymi i co z tego wynika, jeśli chodzi o kierunki działania politycznego, przedstawienie charakterystycznego poczucia ,posłannictwa” KPP oraz reakcji opinii publicznej na fakt działania w Polce partii odwołującej się do komunistycznej ideologii, programu i prze-
\end{abstract}

\begin{abstract}
The article focuses on contemporary Communist Party of Poland - its goals and courses of action, and above all the way CPP refers to the past, how it treats legacy of the Communist Worker's Party of Poland and Communist Party of Poland of interwar period, as well as how it addresses contemporary problems, reaching to the past seen as source of political inspira tions.

The aim of the author of this paper is to describe how historical connection between CPP and former polish communist parties is created and how it affects courses of political action of contemporary CPP; to describe specific sense of "CPP's mission", as well as reactions of polish public opinion to the fact that there is a party which refers to communist ideology, programme and past. On such a basis it is adequate and
\end{abstract}

* Uniwersytet Jagielloński (piotr.obacz@uj.edu.pl), Polskie Towarzystwo Nauk Politycznych (Oddział w Krakowie); ORCID: 0000-0001-6397-2569. 
szłości. Na tej kanwie możliwa i adekwatna jest teoretyczna charakterystyka partii marginalnej.

Analizę oparto na kryteriach teoretycznych dotyczących partii małych, niszowych i marginalnych. $Z$ tej perspektywy możliwe było określenie i objaśnienie charakterystycznych cech współczesnej Komunistycznej Partii Polski właśnie jako partii marginalnej oraz dokonanie oceny potencjału politycznego KPP w rywalizacji politycznej i wyborczej. Wydaje się przy tym - i jest to główna teza artykułu, iż w związku m.in. z radykalizmem KPP, archaicznym programem tej partii, balansowaniem na granicy delegalizacji i innymi uwarunkowaniami politycznymi oraz tymi przewidzianymi teorią, Komunistyczna Partia Polski pozostanie jedynie tzw. fringe party, której przekaz jest niezrozumiały w kontekście norm i przekonań politycznych mieszczących się $\mathrm{w}$ obecnym horyzoncie politycznym współczesnej Polski.

Slowa kluczowe: fringe parties, komunizm, Komunistyczna Partia Polski, partie małe, partie marginalne, partie niszowe, partie polityczne possible to characterize in theoretical manner the marginal party.

The analysis is based on theoretical criteria concerning small, niche and marginal parties. From this theoretical perspective it is possible to identify and explain characteristic, substantial features of contemporary Communist Party of Poland as a marginal party, and to evaluate political potential of this party within electoral and political competition. It is claimed, and this is the main thesis of this paper, that since the radicalism of CPP, it's archaic programme, balancing on the brink of banning, as well as other political circumstances, Communist Party of Poland will remain just so called fringe party, which ideological and political message seem to be incomprehensible in the context of norms and dominating beliefs falling within political horizon of contemporary Poland.

Key words: communism, Communist Party of Poland, fringe parties, marginal parties, niche parties, political parties, small parties

\section{Wprowadzenie}

Nurtujące i zarazem naukowo inspirujące jest odczucie, że pewne zjawiska i podmioty należą już do przeszłości i teraz nie występują, a nawet jeśli coś z nich pozostało lub jeśli próbuje się je odtwarzać, to są to działania kuriozalne. Zapewne odczucie takie częściej jest udziałem historyków niż politologów, jednak politolodzy również mogą podobnie odnosić się do faktu, że pewne byty polityczne przestają istnieć $\mathrm{w}$ znanych formach, a formy nowe są jedynie zdumiewającym dowodem ludzkiej zdolności do tworzenia pewnych „fantomów”. Takim „fantomem” wydaje się współczesna Komunistyczna Partia Polski (KPP) - wytwór fantazji politycznej, zakotwiczonej w mylnych interpretacjach historycznych, osobliwym pojmowaniu rzeczywistości społecznej.

Dzisiejsza KPP nie jest przedmiotem zainteresowania badaczy, a to ze względu na nikłe znaczenie polityczne tej partii. Niemniej, marginalna pozycja wydaje się zjawiskiem ugrupowania interesującym, a jednak relatywnie mało 
omówionym na gruncie polskiego piśmiennictwa naukowego. Jest to zatem asumpt do podjęcia próby teoretycznej charakterystyki marginalności. Dlatego też celem postawionym w niniejszym opracowaniu jest odtworzenie wyróżników marginalności partii politycznej i podanie przykładu, który koresponduje z tymi kryteriami teoretycznymi.

Analizę oparto na kryteriach teoretycznych dotyczących partii małych, niszowych i marginalnych. $Z$ tej perspektywy możliwe było określenie i objaśnienie charakterystycznych cech współczesnej Komunistycznej Partii Polski właśnie jako partii marginalnej oraz dokonanie oceny potencjału politycznego KPP w rywalizacji politycznej i wyborczej. Wydaje się przy tym — i jest to główna teza w artykule - iż w związku między innymi z radykalizmem KPP, archaicznym programem tej partii, balansowaniem na granicy delegalizacji i pozostałymi uwarunkowaniami politycznymi oraz tymi przewidzianymi w teorii, KPP pozostanie jedynie tzw. fringe party - partią marginesu politycznego, partią marginalną — której przekaz jest niezrozumiały w kontekście norm i przekonań politycznych mieszczących się w horyzoncie politycznym współczesnej Polski.

W następnej części artykułu przedstawiono obecną sytuację KPP oraz opisano wyraźne poczucie związku tej partii z dawnymi polskimi ugrupowaniami komunistycznymi, które znacząco oddziałuje na ideologiczny charakter współczesnej KPP i jednocześnie stanowi jeden z głównych czynników przyczyniających się do marginalizacji tej partii. Dalej objaśniono, czym wyróżniają się i czym różnią się od siebie partie małe, niszowe i marginalne, a także scharakteryzowano KPP jako partię marginalną. Artykuł zakończony jest zwięzłym podsumowaniem, zawierającym wnioski z analizy oraz wskazanie pól wymagających dalszych badań politologicznych.

\section{Komunistyczna Partia Polski dziś}

Dzieje ruchu komunistycznego na ziemiach polskich, nawet jeśli nie można uznać ich za szczególne z perspektywy rozwoju komunizmu w tej części świata, są relatywnie bogate. Począwszy od 1893 roku aż do roku 1990 — od zawiązania Socjaldemokracji Królestwa Polskiego i Litwy (SDKPiL), przez Komunistyczną Partię Robotniczą Polski (KPRP, 1918 - 1925), Komunistyczną Partię Polski (KPP, 1925-1938), Polską Partię Robotniczą (PPR, 1942-1948), na Polskiej Zjednoczonej Partii Robotniczej (PZPR, 1948-1990) kończąc; od internacjonalistycznie zorientowanego marksizmu, przez propagowanie komunistycznych ideałów politycznych, realizację wizji radzieckich mocodawców polskich komunistów, do skorumpowanej i niezdolnej do utrzymania władzy PZPR. Co więcej, w sensie organizacyjnym, ideologicznym i politycznym ruch 
komunistyczny przeszedł niezwykle ciekawą ewolucję, na trwałe zapisując się w historii politycznej Polski' ${ }^{1}$.

Co się tyczy dawnej KPP, badania tej historycznej organizacji - głównie prowadzone przez historyków, rzadziej przez politologów - dotyczą przede wszystkim trzech aspektów funkcjonowania Komunistycznej Partii Polski: praktyki politycznej, taktyki politycznej (w tym analizy stanowisk partii wobec głównych procesów społecznych i politycznych) oraz myśli politycznej, programu i ideologii ${ }^{2}$. Co jednak ze współczesną KPP — bo ona jest przedmiotem tego artykułu? Środowisko obecnej KPP odwołuje się do swojej poprzedniczki z lat 1925-1938, działając politycznie już blisko dwadzieścia dziewięć lat, tj. od 1990 roku. Wtedy została założona, w dużej mierze przez byłych członków PZPR, a mówiąc precyzyjnie, przez tzw. Grupę Inicjatywną, partia o nazwie: Związek Komunistów Polskich „Proletariat”. Pod koniec lat dziewięćdziesiątych podjęte zostały pierwsze próby delegalizacji partii, do czego doszło na początku lat $2000^{3}$. Nie czekając, członkowie byłego „Proletariatu” zdecydowali się utworzyć nową organizację i w lipcu 2002 roku zarejestrowali Komunistyczną Partię Polski; numer w ewidencji partii politycznych: 152. Przewodniczącym partii jest Krzysztof Szwej. KPP liczy, wedle różnych źródeł, ok. 1000 członków.

Obecna KPP, konsekwentnie od czasów „Proletariatu”, „to partia typu leninowskiego. W założeniach jest partią rewolucyjną o masowym charakterze" KPP odwołuje się do postaw antyimperializmu i internacjonalizmu; wypowiada się przeciwko „demokracji burżuazyjnej” i kapitalizmowi; w programie partii „napisano, iż najważniejszym zadaniem partii jest przygotowanie światowej klasy robotniczej do świadomej walki o wyeliminowanie wszelkiego wyzysku poprzez budowę społeczeństwa bezklasowego i światowego systemu socjalistycznego 5 . Komunistyczna Partia Polski artykułuje wartości, cele i zadania partii komunistycznej znane z przekazu historycznego, określa marksizm-leninizm mianem swojej doktryny ${ }^{6}$. Jednocześnie próbuje cały czas dostosowywać swój program do wyzwań współczesności. Wydaje czasopismo „Brzask”, stara się

${ }^{1}$ Uwaga ta tyczy się w ogóle polskiej lewicy, w tym lewicy radykalnej. Ewolucję lewicowego „paradygmatu” ideowo-politycznego przedstawił Rafał Chwedoruk w swym wystąpieniu podczas IV Ogólnopolskiego Kongresu Politologii (Lublin, Uniwersytet Marii Curie-Skłodowskiej, 18-20.09.2018), wystąpienie nosiło tytuł: „Lewica wobec państwa. Między etatyzmem a anarchizmem".

${ }^{2}$ Zob. K. Trembicka: Między apologia a negacją. Studium myśli politycznej Komunistycznej Partii Polski w latach 1918-1932. Lublin 1995.

${ }^{3}$ Leksykon polskich partii politycznych. Red. R. Glajcar, A. Turska-KaWa, W. WoJTASIK. Toruń 2017, s. 657-658.

${ }^{4}$ Ibidem, s. 113.

5 Ibidem, s. 114.

${ }^{6}$ https://kom-pol.org/program/ (dostęp: 28.11.2018).

${ }^{7}$ https://kom-pol.org/brzask/ (dostęp: 28.11.2018). 
włączać w działania światowego ruchu komunistycznego (przede wszystkim w prace Inicjatywy Partii Komunistycznych i Robotniczych) ${ }^{8}$.

Komunistyczna Partia Polski jawi się jako klasyczna partia rewolucyjna, antykonstytucyjna (bo odrzuca porządek konstytucyjny) i — na co wszystko wskazuje - antysystemowa (dąży bowiem do trwałego osłabienia i w końcu załamania legitymizacji systemu) ${ }^{9}$. Właśnie między innymi dlatego od wielu lat podnoszone są głosy, iż KPP należy zdelegalizować za promowanie komunizmu, jednak, pomimo ingerencji w tę kwestię przedstawicieli władz państwowych, na razie do tego nie doszło ${ }^{10}$.

Środowisko obecnej KPP, jak już powiedziano, „uważa się za historyczną i ideową spadkobierczynię"11 dawnej KPP oraz SDKPiL i KPRP. Obiektywnie jest to jednak bardziej obciążenie niż walor, a zarazem bodaj główny czynnik ideologiczno-programowy przyczyniający się do marginalizacji tej partii i powodujący szczególny jej odbiór społeczny. Historia KPP, jak ocenia Paweł Śpiewak, była „krótka i wyjątkowo nieszczęśliwa”" ${ }^{2}$. Wydaje się, iż to zasadna opinia, biorąc pod uwagę okoliczności funkcjonowania KPP w II RP, relacje polskich komunistów z towarzyszami radzieckimi i traumatyczne okoliczności rozwiązania partii ${ }^{13}$. U obecnych kapepowców widać wyraźny podziw dla „cnót” dawnych komunistów: zaangażowania, gotowości do poświęceń i wyrzeczeń w imię sprawy, twardości charakteru, a także aspirowanie do tych wartości ${ }^{14}$. Jednocześnie dosłowne i niemal całkowite „kopiowanie” myśli politycznej dawnej KPP do obecnych warunków wydaje się tyleż fascynujące, co groteskowe. Mimo że obecna KPP odżegnuje się od przemocy politycznej jako metody walki o władzę, to wciąż jej przekaz jest taki, jak jej historycznej poprzedniczki: pod-

${ }^{8}$ https://kom-pol.org/swiatowy-ruch-komunistyczny/ (dostęp: 28.11.2018).

9 Por. R. Herbut: Teoria i praktyka funkcjonowania partii politycznych. Wrocław 2002, s. $133-135$.

${ }_{10}$ Zob. np. PiS idzie na wojnę z komunistami. Chce delegalizacji Komunistycznej Partii Polski. Wyborcza.pl — http://wyborcza.pl/1,75398,15455581,PiS_idzie_na_wojne_z_komunistami_Chce_delegalizacji.html (dostęp: 28.11.2018); Komunistyczna Partia Polski wciąż działa. Ale dziś może świętować po raz ostatni. Wp.pl - https://wiadomosci.wp.pl/ komunistyczna-partia-polski-wciaz-dziala-ale-dzis-moze-swietowac-po-raz-ostatni-611 6845134513793a (dostęp: 28.11.2018); PiS nie zdołat zdelegalizować komunistów. Rp.pl https://www.rp.pl/Rzad-PiS/304049927-PiS-nie-zdolal-zdelegalizowac-komunistow.html (dostęp: 28.11.2018); Pisowska delegalizacja KPP wkrótce. Następni sa Razem, a za nimi kolejni, aż zostanie tylko PiS. Kom-pol.org — https://kom-pol.org/2018/03/09/pisowskadelegalizacja-kpp-wkrotce-nastepni-sa-razem-a-za-nimi-kolejni-az-zostanie-tylko-pis/(dostęp: 28.11.2018).

${ }^{11}$ Leksykon polskich partii..., s. 113.

12 P. ŚPIEWAK: Żydokomuna. Interpretacje historyczne. Warszawa 2012, s. 107.

13 Okoliczności związane z rozwiązaniem KPP wciąż budzą wiele kontrowersji i zrozumiałe zainteresowanie. Do kwestii tej odniósł się ostatnio Eryk Krasucki: Czarne dni czerwonych. „Polityka” 2018, nr 50 (3190), s. 56-59.

${ }^{14}$ P. ŚPIEwaK: Żydokomuna..., s. 123. 
szyty pewną „totalitarną gnozą polityczną”, jak określa to Krystyna Trembicka, opartą na przeświadczeniu o upadku starego świata i konieczności budowy nowego ${ }^{15}$. Cytowana autorka przypomina również, że antenatka obecnej KPP w istocie „nie miała własnej wizji państwa” — ta, którą oferowała, była wtórna wobec koncepcji radzieckich ${ }^{16}$.

Swoiste zapatrzenie się współczesnych komunistów w idealizowaną przeszłość utrudnia im, jak można twierdzić, taki sposób myślenia i działania politycznego, które nie zbliżałyby się do doktrynerstwa (trzymania się dogmatycznych poglądów i schematów myślowych) i sekciarstwa (zasklepiania się W obrębie wąskiej grupy ideowo-politycznej) ${ }^{17}$, politykierstwa ${ }^{18}$, dogmatyzmu, posługiwania się czarno-białą wizją świata ${ }^{19}$, a nade wszystko negowania otaczającej rzeczywistości, istniejących związków, wspólnot i form politycznych ${ }^{20}$.

$\mathrm{Na}$ tym tle odwołania do starej KPP wydają się nieadekwatne w kontekście bieżących uwarunkowań społeczno-politycznych i niepotrzebne ze względów historycznych. Co więcej, należy przypomnieć, że „KPP nie była partią liczną, nie należała też do organizacji politycznych posiadających bardzo szerokie wpływy w społeczeństwie, nie zdołała również objąć swym zasięgiem większości polskiej klasy robotniczej” ${ }^{21}$, a zatem trudno stawiać ją za wzór politycznej sprawności. Co więcej, należy nadmienić, iż „polscy komuniści byli społecznie izolowani i nieakceptowani" 22 , a popieranie komunizmu i partii komunistycznej było na swój sposób stygmatyzujące i powodowało społeczne podziały ${ }^{23}$. Doświadczenie komunizmu dzieliło również wiele lat później, po 1989 roku, czego wyrazem podział postkomunistyczny, którego ostatnie ślady zatarły się relatywnie niedawno ${ }^{24}$.

Należy odnotować, że KPP okresu międzywojnia wywierała wpływ na życie społeczno-polityczne, a to między innymi poprzez propagowane idei marksizmu-leninizmu i w pewnym zakresie kształtowanie pod względem ideo-

${ }^{15}$ K. Trembicka: Model państwa Komunistycznej Partii Polski — projekt totalitarny. W: Radykalna lewica na ziemiach polskich w latach 1893-1938: SDKPiL, KPRP, KPP. Red.

R. Rauba. Zielona Góra-Głogów 2009, s. 91.

16 Ibidem.

17 A. Czubiński: Komunistyczna Partia Polski (1918-1938). Zarys historii. Warszawa 1988, s. 304; P. ŚPIEWAK: Żydokomuna..., s. 130-132.

${ }_{18}$ M. KARWAT, J. ZióŁKowski: Leksykon pojęć politycznych. Warszawa 2013, s. 254.

19 P. ŚPIEWAK: Żydokomuna ..., s. 132.

${ }^{20}$ Por. ibidem, s. $132-135$.

${ }^{21}$ B. Kolebacz: Komunistyczna Partia Polski 1923-1929. Problemy ideologiczne. Warszawa 1984, s. 5.

${ }^{22}$ P. ŚPIEWAK: Żydokomuna ..., s. 122.

23 Ibidem, s. 123.

${ }^{24}$ M. Grabowska: Podziat postkomunistyczny. Spoleczne podstawy polityki w Polsce po 1989 roku. Warszawa 2004; P. ŚPIEwaK: Pamięć po komunizmie. Gdańsk 2005; zob. także P. ОвасZ: Podziat „Polska solidarna - Polska liberalna” w świetle wybranych koncepcji pluralizmu politycznego. Kraków 2018. 
logicznym i politycznym polskiego ruchu robotniczego ${ }^{25}$. W żadnej mierze nie sposób odnieść tego do KPP działającej obecnie. Skala potencjału partii i jej faktycznego znaczenia politycznego są jednymi z mierników marginalności danego ugrupowania.

\section{KPP jako partia marginalna}

Komunistyczna Partia Polski jest partią niemainstreamową i przez analogię z innymi partiami spoza głównego nurtu politycznego można zasadnie spodziewać się, że taka partia jest: mała pod względem kadrowym oraz mało znacząca politycznie (mały, ograniczony, nikły wpływ na agendę spraw politycznych lub brak wpływu). Partie tego typu bardzo często opisuje się następująco: „Bez dotacji i szans na sukces. Ideowo dzieli je wszystko, ale łączy je beznadziejna sytuacja i chęć do walki. Chcą ratować kraj, choć same walczą o przetrwanie. To partie, które dla przeciętnego wyborcy są za małe, by mógł je dostrzec. Ludzie albo o nich zapomnieli, albo nigdy nie mieli okazji usłyszeć”26. „Pomimo różnic, partie alternatywne mają jedną rzecz wspólną: są w większości zmarginalizowane. [...] Na peryferiach życie polityczne wygląda inaczej" ${ }^{27}$. Co zatem wyróżnia partie marginalne i czym różnią się od partii niszowych oraz partii małych?

Partie małe wyczerpująco scharakteryzował Piotr Sula w wydanej niedawno monografii poświęconej tym podmiotom polityki. W sformułowanej przez tego autora teorii istotny jest próg partii małej — próg przede wszystkim dla graczy parlamentarnych, inny $\mathrm{w}$ różnych państwach $\mathrm{w}$ zależności od kształtu sceny partyjnej, na który to próg składają się takie czynniki, jak: poziom poparcia dla partii, poziom udziału w politycznym mainstreamie, poziom udziału w polityce parlamentarnej, przetargach koalicyjnych i rządach. Istotne jest to, gdzie lokują się partie małe w przestrzeni rywalizacji politycznej, to, czy są uznawane przez wyborców za wiarygodnych reprezentantów oraz jakie kwestie (issues) podnoszą. Te czynniki decydują o trwaniu partii małych, przy czym status partii małej może być oczywiście zmienny ${ }^{28}$. „Mały” jest tu pojęciem względnym,

25 B. Kolebacz: Komunistyczna Partia Polski 1923-1929..., s. 5 i n.

${ }^{26}$ P. Witwicki: Niszowe partie, czyli życie na politycznym marginesie. 300polityka.pl, 3.08.2018 - http://300polityka.pl/news/2013/08/02/niszowe-partie-czyli-zycie-na-politycz nym-marginesie/ (dostęp: 28.11.2018).

27 P. Hruby: Fringe Candidates Party on beyond the Mainstream. The Washington Times, 7.03.2012 — https:/www.washingtontimes.com/news/2012/mar/7/fringe-political-partieswait-for-unfulfilled-vote/ (dostęp: 28.11.2018).

${ }_{28}$ P. Sula: Partie małe w wybranych państwach Europy Środkowo-Wschodniej w latach 1989-2016. Kraków 2018, s. 31—45. 
definiowanym przede wszystkim podług rezultatów wyborczych i politycznej efektywności w ramach głównego nurtu życia politycznego.

Wśród badaczy, którzy zajmują się specyfiką partii niszowych, należy wymienić zwłaszcza nazwiska Bonnie Meguid, Jamesa Adamsa oraz Markusa Wagnera. Adams i zespół argumentują, że to radykalne ideologie określają niszowość; Meguid - że wąski zakres issues, które wykraczają poza linie podziałów; Wagner zaś - że partie niszowe to takie, które przenoszą akcent programowy z kwestii ekonomicznych na wąski zakres nieekonomicznych kwestii ${ }^{29}$. Istotne jest, że partie niszowe rzadziej niż więksi, mainstreamowi gracze odpowiadają na zmiany w obrębie opinii publicznej - a zatem stosują odmienne taktyki polityczne i strategie wyborcze, ale jednocześnie podejmują kwestie, którymi nie zajmują się ci gracze, i umiejętnie lokują się w ideowo-politycznych „niszach" - stąd ich potencjał ${ }^{30}$. Niszowość to pojęcie określające właściwość podmiotu politycznego, który poprzez swoją odmienność ideologiczno-programową od podmiotów głównego nurtu politycznego może nigdy do tego nurtu nie dołączyć lub pozostawać na jego obrzeżach, niemniej jednak jego przekaz, cele i (wąski) zakres kwestii, którymi się zajmuje, powodują, że udaje mu się ,umościć" w pozycji umożliwiającej aktywny udział w życiu politycznym.

Zwraca uwagę to, że partie marginalne podzielają pewne cechy z partiami małymi i partiami niszowymi; „małość” i „niszowość” łączą się w partiach marginalnych, choć bardziej w zakresie cech negatywnych aniżeli pozytywnych oddziaływań na otoczenie polityczne. Należy przy tym podkreślić, że marginalność jednoznacznie określa nikłe znaczenie partii, podczas gdy „małość” i „niszowość" już niekoniecznie — te ostatnie mogą wskazywać, że choć partia nie ma silnej i/lub stabilnej pozycji w systemie partyjnym, to na przykład zajmując się wąskim wycinkiem istotnych społecznie spraw, zapewnia sobie poparcie pozwalające jej utrzymać się $\mathrm{w}$ grze politycznej. Partie marginalne mają $\mathrm{z}$ tym problem, a ich trwałość lub nawet dalsza organizacyjna egzystencja są istotnie zagrożone ${ }^{31}$. Co więcej, partie marginalne nie mają wpływu na tok debaty publicznej czy kierunek polityk i nie są uwzględniane - ani przez obywateli, ani przez szeroko rozumiane otoczenie polityczne - jako takie, które są zdolne

${ }^{29}$ M. Wagner: Defining and Measuring Niche Parties. "Party Politics" 2011, No 18(6); J. Adams et Al.: Are Niche Parties Fundamentally Different from Mainstream Parties? The Causes and the Electoral Consequences of Western European Parties' Policy Shifts, 1976-1998. "American Journal of Political Science" 2006, No 50(3); B. Meguid: Competition between Uneqals. The Role of Mainstream Party Strategy in Niche Party Success. "Amercian Political Science Review" 2005, No 99(3); Eadem: Party Competition between Unequals. Strategies and Electoral Fortunes in Western Europe. Cambridge 2008.

30 Zob. także Th. Meyer, B. Miller: The Niche Party Concept and its Measurement. "Party Politics" 2013, No 21(2).

${ }^{31}$ Por. M. Wagner: Defining and Measuring Niche Parties..., s. 849. 
do efektywnego działania ${ }^{32}$. Termin „,marginalny” znaczy tyle, co mało istotny. Marginalna partia to taka, która nie odgrywa ważnej roli — jest mało ważna lub zupełnie nieważna, biorąc pod uwagę funkcje, jakie powinna wypełniać; partia marginalna nie wpływa na nic, nie wyznacza kierunków działania instytucji czy grup ludzi, a do tego ma małe możliwości i zasoby, by wpływ taki osiągnąć.

\section{Powody marginalności - przykład KPP}

Marginalność stanowi cechę, właściwość, w przypadku, o którym tu mowa - partii politycznej. Powody marginalizacji, rozumianej jako proces spadku i zaniku znaczenia danego podmiotu, którego to procesu marginalność jest finalnym stanem, są złożone i dwojakiego rodzaju: mogą być niezależne od podmiotu i/lub mogą być wynikiem jego własnych poczynań. W pierwszej sytuacji mowa będzie przede wszystkim o działaniach otoczenia politycznego wobec danej partii, w drugim zaś - o niewłaściwych, niekonsekwentnych, niepopularnych, niezrozumiałych, nieakceptowanych przez otoczenie społeczno-polityczne działaniach danej partii. Powody (samo)marginalizacji KPP są głównie tej drugiej natury. Wśród nich należy wymienić:

- formułowanie przekazu politycznego, który nie koresponduje z głównymi liniami podziału społeczno-politycznego, a dodatkowo ma charakter radykalny i archaiczny ze względów historycznych;

- ignorowanie przez partię bieżących uwarunkowań społeczno-ekonomicznych, społeczno-politycznych oraz instytucjonalnych;

- unikanie budowania szerokich platform programowych i politycznych;

— przyjmowanie nieefektywnych strategii i taktyki rywalizacji politycznej ${ }^{33}$.

\section{Cechy partii marginalnej - przykład KPP}

To, co stanowi o powodach marginalizacji partii, uznać można zwrotnie także za cechy szczególne partii marginalnej. Należy jednak dodać kolejne wyróżniki marginalności, pozwalające stwierdzić, iż marginalność jest zjawiskiem syndromatycznym:

— balansowanie na granicy uznawalności za partię polityczną ${ }^{34}$;

32 Por. K.J. Han: What Makes Niche Parties Niche Parties? Past Election Result, Issue Salience, and the Nicheness of Niche Parties — https://pages.wustl.edu/cpac/hancpac2015 (dostęp: 28.11.2018).

33 Por. P. Sula: Partie mate..., s. 37-39.

${ }^{34}$ K. Trembicka: Między utopiq a rzeczywistościq. Myśl Komunistycznej Partii Polski (1918-1938). Lublin 2007, s. 49. 
- słabe wypełnianie lub niespełnianie funkcji partii politycznych ${ }^{35}$;

- nikłe znaczenie polityczne, odzwierciedlone w tym, że partia nie kształtuje agendy politycznej i nie ma wpływu na decyzje polityczne ani na ewolucję systemu partyjnego ${ }^{36}$;

— nikły potencjał polityczny, mierzony między innymi: oddziaływaniem na inne partie i podmioty polityki, rozwój struktur partyjnych, rozwój kadrowy, udział w wyborach, propagowanie swych idei, zdolności mobilizacyjne, poparcie ${ }^{37}$

— problemy z utrzymaniem własnej zdolności do organizacji i przetrwania partii ${ }^{38}$;

— problemy $\mathrm{z}$ reagowaniem na bieżące wyzwania społeczno-polityczne w związku ze stanowiskiem ideologicznym ${ }^{39}$;

- brak działań, które spinałyby partię ze społeczeństwem, sferą państwowo-instytucjonalną, mechanizmami politycznymi ${ }^{40}$, a zatem dysfunkcjonalność wobec układu społeczno-politycznego ${ }^{41}$.

\section{Implikacje marginalności — perspektywy KPP}

Łatwo zatem przewidzieć implikacje marginalności. Partia marginalna po prostu „egzystuje”, z trudem jest zdolna do efektywnego realizowania zadań partii politycznej (bądź całkowicie tę zdolność utraciła) - spełniania funkcji: integracyjnej, mobilizacyjnej, partycypacyjnej, organizacyjnej, wyborczej, kształtowania opinii publicznej, artykulacji i agregacji interesów, rekrutacji $\mathrm{kadr}^{42}$. Można się zatem spodziewać, iż nie dojdzie do ,autoryzacji” KPP po-

${ }^{35}$ Demokracje zachodnioeuropejskie. Analiza porównawcza. Red. A. AnToszewski, R. Herbut. Wrocław 2008, s. 97-104; K. Sobolewska-Myślik: Partie i systemy partyjne na świecie. Warszawa 2010, s. 24-29; W. Rafalowski: Opisywanie i wyjaśnianie systemu partyjnego. Metody pomiaru. Warszawa 2017, s. 11-13; K.A. WoJtaszczyK: Partie polityczne w państwie demokratycznym. Warszawa 1998, s. 16-21.

${ }^{36}$ D. Kasprowicz: Dlaczego partia? Polskie partie pozaparlamentarne w procesie konceptualizacji partii politycznej. W: Partie polityczne w Polsce $i$ w Europie. Struktury, funkcje, strategie w zmieniajacym się otoczeniu. Red. A. Pacześniak, M. WinceawsKa. Toruń 2013, s. 225; W. Rafalowski: Opisywanie i wyjaśnianie systemu..., s. 11-13.

${ }^{37}$ K. Trembicka: Między utopia a rzeczywistościa..., s. 50.

${ }^{38}$ K.A. WojtaszczyK: Partie polityczne w państwie..., s. 16-21.

39 Por. A. PaCzeŚniak, M. Winceawska: Kryzys w partiach czy odpowiedź na wyzwania wspótczesności? W: Partie polityczne w Polsce i w Europie..., s. 5.

40 A. Materska-Sosnowska: Partie w kryzysie. W: Partie polityczne w Polsce $i$ w Europie..., s. 344 .

${ }^{41}$ R. Herbut: Teoria i praktyka..., s. 134.

${ }^{42}$ Demokracje zachodnioeuropejskie. Analiza..., s. 97-104; K. Soвolewska-MrśLik: Partie i systemy partyjne..., s. 24-29; W. Rafalowski: Opisywanie i wyjaśnianie systemu..., s. 11-13; K.A. Wojtaszczyк: Partie polityczne w państwie..., s. 16-21. 
przez dopuszczenie do wyborów, partia nie sprawdzi się w bieżącej rywalizacji politycznej, nie będzie podmiotem uczestniczącym w przetargach koalicyjnych na różnych szczeblach ${ }^{43}$, oraz że pozostanie pewnym kuriozum, „ciekawostką” wywołującą oburzenie części środowisk społeczno-politycznych.

\section{Podsumowanie}

Komunistyczna Partia Polski dziś — to nieudolna kopia, oparta na fałszywej pamięci, naiwnych wyobrażeniach politycznych; to modelowa partia marginalna, niezdolna do właściwego rozpoznania zróżnicowanych potrzeb społecznych, trafnej identyfikacji problemów i adekwatnych do nich rozwiązań, wykorzystujących narzędzia współczesnej polityki, technologii, komunikacji i zarządzania. Co więcej, wraz z biegiem lat zmieniła się wartość ideologiczna i polityczna KPP jako partii komunistycznej, zmieniło się również otoczenie wewnętrzne i międzynarodowe - dlatego też kurczowe trzymanie się przez współczesnych kapepowców dawno nieaktualnej linii politycznej historycznej poprzedniczki wydaje się pozbawione obiektywnego sensu.

O ile dawną KPP uznać można za „fenomen sytuacyjny, który należy rozpatrywać w kontekście konkretnego układu społeczno-politycznego" ${ }^{\text {,4 }}$, o tyle współczesna KPP to typowa organizacja marginalna, nieprzystosowana do systemu i niemogąca konkurować z innymi ugrupowaniami, bo niemająca ku temu różnorodnych zasobów, a dodatkowo pogrążająca się na gruncie ideologiczno-programowym. W związku z tym jest „dysfunkcjonalna wobec demokratycznych układów politycznych, kwestionując m.in. ich legitymację społeczną, zasady gry politycznej czy nawet zdolność zaspokajania enigmatycznie rozumianych potrzeb społecznych" ${ }^{\circledR 5}$.

\section{Dyskusja — perspektywy dalszych badań}

Wydaje się celowe prowadzenie dalszych pogłębionych badań nad zjawiskiem marginalności partii politycznych, aby pełniej opisać ten złożony fenomen i przede wszystkim określić empiryczny sens marginalności, wyrażając go

\footnotetext{
${ }^{43}$ Por. P. Sula: Partie mate..., s. 11-45.

${ }^{44}$ R. Herbut: Teoria i praktyka..., s. 134.

${ }^{45}$ Ibidem.
} 
językiem teorii politycznej. Nie mniej godne zainteresowania badaczy jest także między innymi to, jak kształtuje się etos współczesnych partii komunistycznych i jak funkcjonuje on na przykład w takich uwarunkowaniach, jak polskie, gdzie partia uważająca się za spadkobierczynię dawnej KPP jest na politycznym „marginesie marginesu”. Konieczna jest także dalsza praca teoretyczna nad demarkacją granicy między polityczną małością, niszowością, peryferyjnością i marginalnością oraz nad tym, jakie mechanizmy występują przy „przejściach” między tymi politycznymi stanami.

\section{Bibliografia}

Abou-Chadi T.: Niche Party Success and Mainstream Party Policy Shifts - How Green and Radical Right Parties Differ in Their Impact. "British Journal of Political Science"2014, No 46(2).

Adams J. ET AL.: Are Niche Parties Fundamentally Different from Mainstream Parties? The Causes and the Electoral Consequences of Western European Parties' Policy Shifts, 1976-1998. "American Journal of Political Science” 2006, No 50(3).

Demokracje zachodnioeuropejskie. Analiza porównawcza. Red. A. AntoszewsKi, R. Herbut. Wrocław 2008.

Antoszewski A., Herbut R.: Systemy polityczne współczesnego świata. Gdańsk 2001.

Borghetto E.: The Issue Strategies of Niche Parties between Elections: An Analysis of Question Time in Six Countries. Paper presented at the 2018 ECPR General Conference in Hamburg — https://enricoborghetto.netlify.com/working_paper/ hamburg_niche_2018.pdf (dostęp: 28.11.2018).

Cimek H., Kieszczyński L.: Komunistyczna Partia Polski: 1918-1938. Warszawa 1985.

Czubiński A.: Komunistyczna Partia Polski (1918-1938). Zarys historii. Warszawa 1988.

Czyżniewski M.: Komunistyczna Partia Czech i Moraw jako element demokratycznego systemu partyjnego. W: Między idealizmem a pragmatyzmem. Wyzwania dla współczesnych partii politycznych. Red. M. WincŁaWsKA, M. STRzeleCKI. Toruń 2017.

Dziewanowski M. K.: The Communist Party of Poland. An Outline of History. Cambridge 1976.

Ezrow L.: Research Note: On the Inverse Relationship between Votes and Proximity for Niche Parties. "European Journal of Political Research" 2008, No 47(2).

GrabowsKa M.: Podziat postkomunistyczny. Społeczne podstawy polityki w Polsce po 1989 roku. Warszawa 2004. 
Han K.J.: What Makes Niche Parties Niche Parties? Past Election Result, Issue Salience, and the Nicheness of Niche Parties — https://pages.wustl.edu/cpac/ hancpac2015 (dostęp: 28.11.2018).

HeRbUt R.: Teoria i praktyka funkcjonowania partii politycznych. Wrocław 2002.

Hruby P.: Fringe Candidates Party on beyond the Mainstream. The Washington Times, 7.03.2012 — https:/www.washingtontimes.com/news/2012/mar/7/fringepolitical-parties-wait-for-unfulfilled-vote/ (dostęp: 28.11.2018).

https://kom-pol.org/program/ (dostęp: 28.11.2018).

https://kom-pol.org/brzask/ (dostęp: 28.11.2018).

https://kom-pol.org/swiatowy-ruch-komunistyczny/ (dostęp: 28.11.2018).

Kasprowicz D.: Dlaczego partia? Polskie partie pozaparlamentarne $w$ procesie konceptualizacji partii politycznej. W: Partie polityczne $w$ Polsce $i w$ Europie: struktury, funkcje, strategie $w$ zmieniajacym się otoczeniu. Red. A. PACZEŚNIAK, M. WincŁaWsKa. Toruń 2013.

KieszCZyŃski L.: Komunistyczna Partia Polski a ruch zawodowy 1918-1938. Warszawa 1990.

Kolebacz B.: Komunistyczna Partia Polski 1923-1929. Problemy ideologiczne. Warszawa 1984.

Komunistyczna Partia Polski. Informator o materiałach archiwalnych z lat 1918 1939, przechowywanych $w$ archiwach polskich. Red. M. NASzKOwsKi. Warszawa 1971.

Komunistyczna Partia Polski — https://kom-pol.org/ (dostęp: 28.11.2018).

Komunistyczna Partia Polski wciąż działa. Ale dziś może świętować po raz ostatni. Wp.pl — https://wiadomosci.wp.pl/komunistyczna-partia-polski-wciaz-dziala-aledzis-moze-swietowac-po-raz-ostatni-6116845134513793a (dostęp: 28.11.2018).

Komuniści w II Rzeczypospolitej. Ludzie - struktury - działalność. Red. M. BuKaŁA, M. KrzyszTOFiński. Rzeszów 2015.

Kowalski J.: Komunistyczna Partia Polski 1935-1938. Studium historyczne. Warszawa 1975.

Krasucki E.: Czarne dni czerwonych. „Polityka” 2018, nr 50 (3190).

Leiter D.L., Ezrow L.: Partisan Sorting and Niche Parties in Europe. "West European Politics" 2012, No 35(6).

Leksykon pojęć politycznych. Red. M. KARWAT, J. ZIÓŁKowsKI. Warszawa 2013.

Leksykon polskich partii politycznych. Red. R. GlajCAR, A. TursKa-KaWA, W. WoJTASIK. Toruń 2017.

Materska-Sosnowska A.: Partie $w$ kryzysie. W: Partie polityczne $w$ Polsce $i w$ Europie: struktury, funkcje, strategie $w$ zmieniajacym się otoczeniu. Red. A. Pacześniak, M. WincŁaWska. Toruń 2013.

Meguid B.: Competition between Uneqals: The Role of Mainstream Party Strategy in Niche Party Success. "Amercian Political Science Review" 2005, No 99(3).

Meguid B.: Party Competition between Unequals. Strategies and Electoral Fortunes in Western Europe. Cambridge 2008.

Meyer Th., Miller B.: The Niche Party Concept and Its Measurement. "Party Politics" 2013, No 21(2).

NaZARewicz R.: Komintern a lewica polska. Wybrane problemy. Warszawa 2008. 
Овасz P.: Podziat „Polska solidarna - Polska liberalna” w świetle wybranych koncepcji pluralizmu politycznego. Kraków 2018.

PaCzeŚniaK A., Winclawska M.: Kryzys w partiach czy odpowiedź na wyzwania współczesności? W: Partie polityczne $w$ Polsce $i$ w Europie: struktury, funkcje, strategie w zmieniajacym się otoczeniu. Red. A. PaCZeŚniaK, M. WincŁaWsKa. Toruń 2013.

Partia komunistyczna w Polsce: struktury, ludzie, dokumentacja. Red. D. MAGIER. Lublin-Radzyń Podlaski 2012.

Partie komunistyczne a proces rewolucyjny we współczesnym świecie. Red. J. KANTYKA. Katowice 1982.

PiS idzie na wojnę z komunistami. Chce delegalizacji Komunistycznej Partii Polski. Wyborcza.pl — http://wyborcza.pl/1,75398,15455581,PiS_idzie_na_wojne_z_ komunistami_Chce_delegalizacji.html (dostęp: 28.11.2018).

PiS nie zdołat zdelegalizować komunistów. Rp.pl - https://www.rp.pl/Rzad-PiS/ 304049927-PiS-nie-zdolal-zdelegalizowac-komunistow.html (dostęp: 28.11.2018).

Pisowska delegalizacja KPP wkrótce. Następni sa Razem, a za nimi kolejni, aż zostanie tylko PiS. Kom-pol.org — https://kom-pol.org/2018/03/09/pisowskadelegalizacja-kpp-wkrotce-nastepni-sa-razem-a-za-nimi-kolejni-az-zostanie-tyl ko-pis/ (dostęp: 28.11.2018).

Rafalowski W.: Opisywanie $i$ wyjaśnianie systemu partyjnego. Metody pomiaru. Warszawa 2017.

ReguŁa J.A.: Historia Komunistycznej Partii Polski w świetle faktów i dokumentów. Toruń 1994.

Rewolucja w myśli i praktyce politycznej. Red. S. BIELEŃ. Warszawa 2018.

SaCEWICZ K.: Komunizm i antykomunizm w II Rzeczypospolitej. Państwo, spoteczeństwo, partie. Olsztyn 2016.

SACEWICZ K.: Rewolucja komunistyczna i dyktatura proletariatu $w$ świetle publikacji Centralnego Porozumienia Organizacji Współdziałajacych $w$ Zwalczaniu Komunizmu — zarys problemu. „Pamięć i Sprawiedliwość” 2017, nr 2(30).

SACEWICZ K.: Ruch komunistyczny na ziemiach polskich w latach 1918-1923 $w$ świetle materiatów operacyjnych $i$ opracowań agend Ministerstwa Spraw Wewnętrznych II RP. „Echa Przeszłości” 2012, nr 13.

Sartori G.: Parties and Party Systems. A Framework for Analysis. Colchester 2005.

SobolewsKa-MyśLik K.: Partie i systemy partyjne na świecie. Warszawa 2010.

Sula P.: Partie małe $w$ wybranych państwach Europy Srodkowo-Wschodniej w latach 1989-2016. Kraków 2018.

ŚPIEWAK P.: Pamięć po komunizmie. Gdańsk 2005.

ŚPIEWAK P.: Żydokomuna. Interpretacje historyczne. Warszawa 2012.

Świetlikowa F.: Komunistyczna Partia Robotnicza Polski: 1918-1923. Warszawa 1968.

Trembicka K.: Między apologia a negacją. Studium myśli politycznej Komunistycznej Partii Polski w latach 1918-1932. Lublin 1995.

Trembicka K.: Między utopia a rzeczywistościa. Myśl Komunistycznej Partii Polski (1918-1938). Lublin 2007. 
Trembicka K.: Model państwa Komunistycznej Partii Polski - projekt totalitarny. W: Radykalna lewica na ziemiach polskich w latach 1893-1938: SDKPiL, $K P R P, K P P$. Red. R. Rauba. Zielona Góra-Głogów 2009.

Wagner M.: Defining and Measuring Niche Parties. "Party Politics" 2011, No 18(6).

WAGNer M.: Niche Parties. Wagnermarkus.net - https://www.wagnermarkus.net/ niche-parties.html (dostęp: 28.11.2018).

Wardt M. Van De: Desperate Needs, Desperate Deeds. Why Mainstream Parties Respond to the Issues of Niche Parties. "West European Politics" 2015, No 38(1).

WITWICKI P.: Niszowe partie, czyli życie na politycznym marginesie. 300polityka.pl, 3.08.2018 - http://300polityka.pl/news/2013/08/02/niszowe-partie-czyli-zyciena-politycznym-marginesie/ (dostęp: 28.11.2018).

WoJTASZcZYK K.A.: Partie polityczne w państwie demokratycznym. Warszawa 1998.

Wspótczesne partie i systemy partyjne. Zagadnienia teorii i praktyki politycznej. Red. W. SokóŁ, M. ŻMigrodzKi. Lublin 2008.

Zons G.: How Programmatic Profiles of Niche Parties Affect Their Electoral Performance. "West European Politics" 2016, No 39(6).

Piotr Obacz, dr, politolog, teoretyk polityki, pracownik Uniwersytetu Jagiellońskiego, członek Polskiego Towarzystwa Nauk Politycznych, zainteresowania badawcze: teoria polityki, teoria demokracji, historia polityczna Polski, zachowania polityczne. 